
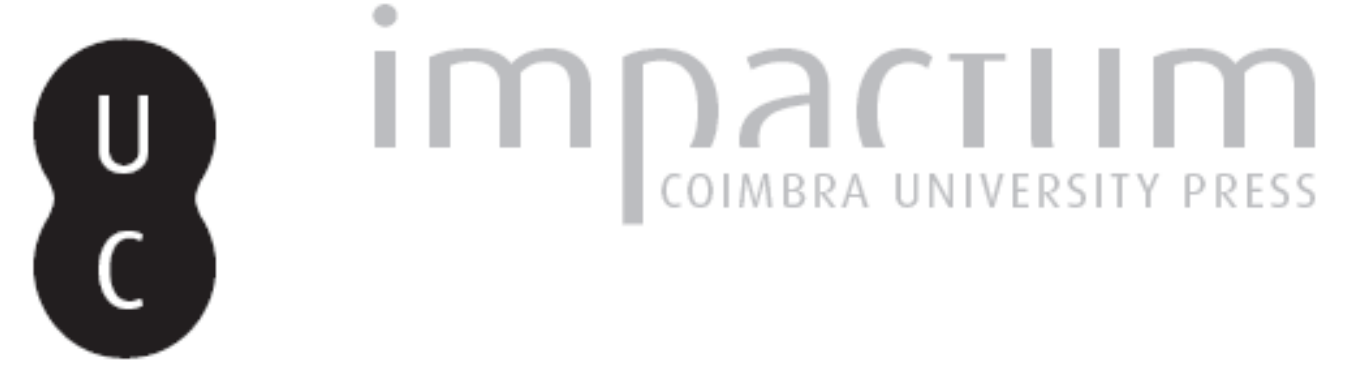

\title{
As lucernas do acampamento militar romano da Lomba do Canho: (Arganil)
}

Autor(es): $\quad$ Nunes, João de Castro; Guerra, Amilcar; Fabião, Carlos

Publicado por: Imprensa da Universidade de Coimbra

URL persistente:

URl:http://hdl.handle.net/10316.2/45546

DOI:

DOI:https://dx.doi.org/10.14195/1647-8657_29_4

Accessed : $\quad$ 26-Apr-2023 15:27:18

A navegação consulta e descarregamento dos títulos inseridos nas Bibliotecas Digitais UC Digitalis, UC Pombalina e UC Impactum, pressupõem a aceitação plena e sem reservas dos Termos e Condições de Uso destas Bibliotecas Digitais, disponíveis em https://digitalis.uc.pt/pt-pt/termos.

Conforme exposto nos referidos Termos e Condições de Uso, o descarregamento de títulos de acesso restrito requer uma licença válida de autorização devendo o utilizador aceder ao(s) documento(s) a partir de um endereço de IP da instituição detentora da supramencionada licença.

Ao utilizador é apenas permitido o descarregamento para uso pessoal, pelo que o emprego do(s) título(s) descarregado(s) para outro fim, designadamente comercial, carece de autorização do respetivo autor ou editor da obra.

Na medida em que todas as obras da UC Digitalis se encontram protegidas pelo Código do Direito de Autor e Direitos Conexos e demais legislação aplicável, toda a cópia, parcial ou total, deste documento, nos casos em que é legalmente admitida, deverá conter ou fazer-se acompanhar por este aviso.

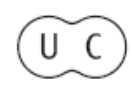


FACULDADE DE LETRAS

INSTITUTO DE ARQUEOLOGIA

CONIMBRIGA

VOLUME XXIX

UNIVERSIDADE DE COIMBRA

1990 
Jõ̃o DE CASTRO NunES **

AMILCAR GUERRA***

CARLOS FABĨ̃O ***

\author{
AS LUCERNAS DO ACAMPAMENTO MILITAR ROMANO DA LOMBA DO \\ CANHO (ARGANIL) * \\ «Conimbriga», XXIX, 1990, 69-90
}

RESUMO: Apresentam-se as lucernas romanas recolhidas no decurso da escavação do acampamento militar da Lomba do Canho, em Arganil. O conjunto inclui dois exemplares do tipo $\mathrm{H}$ de Ricci, seis do tipo Dressel/ Lamboglia 2, um do tipo Dressel/Lamboglia 3, para além de quatro fragmentos que não permitem uma classificação segura. Os exemplares que se conservam in situ documentam uma utilização no âmbito das áreas residenciais, correspondendo cada uma a um compartimento com lareira.

O conjunto apresenta características peculiares típicas do séc. I a. C., com exemplares "tardo-helenísticos" coexistindo com as primeiras produções tipicamente romanas. A comparação com outros conjuntos da Península Ibérica, designadamente Ampúrias e Cáceres el Viejo, permite sugerir uma cronologia no âmbito dos segundo e terceiro quartéis do séc. I a. C. - âmbito cronológico confirmado por outros materiais, como moedas, campanienses, ânforas, fíbulas, etc.

A análise da distribuição dos achados similares no actual território português sugere que a difusão desta forma de iluminação se encontra relacionada com a progressão do exército romano no extremo Ocidente peninsular.

RÉSUMÉ: Les auteurs présentent les lampes romaines du campement militaire de

Lomba do Canho, Arganil (conventus Scallabitanus, Lusitania). L'ensemble est composé de deux exemplaires du type $\mathrm{H}$ de Ricci, six du type Dressel/Lamboglia 2, un du type Dressel/Lamboglia 3 et de quatre autres

* Uma versão mais breve deste texto foi apresentada ao II Colóquio Arqueológico de Viseu (Abril de 1990).

** Professor Associado da Faculdade de Letras de Lisboa. Alameda da Universidade, 1699 Lisboa Codex.

*** Assistente da Faculdade de Letras de Lisboa. Investigador do C.A.H. - I.N.I.C., Alameda da Universidade 1699 Lisboa Codex. 
fragments qui ne permettent pas une classification sûre. Les pièces conservées in situ témoignent une utilisation dans l'espace résidentiel: line lampe près du foyer par compartiment.

L'ensemble, caractéristique du milieu du Ier siècle av. J. C, présente des exemplaires "tardo-héllénistiques" et les premières productions typiquement romaines. Par comparaison avec d'autres ensembles de la Péninsule Ibérique - Ampurias et Cáceres el Viejo - on peut proposer une chronologie du sécond et troisième quarts du Irr siècle av. J. C., ce qui est confirmé par d'autres matériaux (monnaies, campaniennes, amphores, fibules, etc.).

L'analyse de la distribution des pièces semblables de l'actuel territoire portugais laisse penser qu'on peut rapporter ce système d'illumination à la progression de l'armée romaine dans l'extrême Occident péninsulaire.

Conimbriga, 29 (1990), 69-90 


\section{AS LUCERNAS DO ACAMPAMENTO MILITAR ROMANO DA LOMBA DO CANHO (ARGANIL)}

\section{Introdução}

O acampamento militar romano da Lomba do Canho acha-se implantado sobre urna crista quartzítica a cerca de $2 \mathrm{~km}$ a norte da vila de Arganil.

São já numerosos os trabalhos publicados sobre este sitio arqueológico, desde os referentes às primeiras escavações efectuadas na década de 50 pelo primeiro signatário (NuNEs, 1958a, 1958b, 1959), até aos relativos às intervenções que em anos mais próximos ali foram conduzidas, já com a colaboração dos restantes signatários do presente estudo (NuNEs, 1985 e 1986: FARIA, 1982 e 1984-5; FABĨ̃o/GUerRA, 1985-6 e 1987; Guerra/Fabião, 1988; Nunes/Fabião/Guerra, 1988 e 1989). Neles ficou claramente expressa a relevante importância do sítio, com uma ocupação circunscrita ao período tardo-republicano, para o estudo do processo da romanização do actual território português, se é que alguma dúvida restava ainda a esse respeito...

Por tudo isto, com o passar dos anos, mais absurda se vai tomando a situação de impasse em que se encontra o processo de reabertura dos trabalhos arqueológicos, abruptamente interrompidos em 1983 e, desde então, nunca mais retomados. É, portanto, com a firme esperança, que nunca perdemos, de brevemente conseguir ultrapassar o actual estado de coisas e iniciar de novo as escavações na Lomba do Canho, que apresentamos a totalidade das lucernas até hoje recolhidas naquele sítio arqueológico.

O conjunto das lucernas do acampamento militar romano da Lomba do Canho não se encontrava propriamente inédito. A totalidade das peças, quer as reconstituídas, quer os mais simples fragmentos, tem estado exposta numa das vitrines do Museu Regional de Arqueologia de Arganil, desde a sua inauguração, em 1980. Inclusivamente, já foram 
publicadas algumas considerações de ordem genérica sobre estes materiais e, pode dizer-se, o essencial das conclusões que suscitam (GUERRA/ FABIÃo, 1988: 315-6 e Est. VII; Nunes/Fabião/ Guerra, 1988: 19-20 e Fig. 14; Idem, 1989: 409-10, Fig. 8). No entanto, a publicação da totalidade dos materiais, bem como um mais extenso comentário em torno da singularidade deste conjunto e da sua importância, que naturalmente reservávamos para uma publicação definitiva, não tinha sido ainda dado a conhecer.

\section{O conjunto de lucernas}

O conjunto de lucernas da Lomba do Canho enquadra-se no período tardo-republicano. Esta inserção cronológica começa por levantar alguns problemas específicos. De facto, como tem sido referido (PAVolini, 1981: 139; ArXé I Gálvez, 1982: 7), os estudos sobre as lucernas deste período não são muito abundantes em todo o mundo romano e, inclusivamente, conhecem-se melhor as lucernas de épocas helenística e imperial, ou seja, as produções anteriores e posteriores, do que propriamente as respeitantes ao período em causa.

No que diz respeito ao actual território português, basta percorrer as publicações da especialidade para verificar que é difícil encontrar paralelos para o conjunto da Lomba do Canho. As lucernas deste período podem considerar-se raríssimas e provêem geralmente de sítios arqueológicos muito diversificados e de contextos normalmente desconhecidos (v. infra). Esta ausência de termos de comparação levou-nos a procurar um enquadramento para estes materiais num âmbito muito mais amplo do ponto de vista geográfico. Assim, os trabalhos de Ricci (1973) e Pavolini (1981), para a Península Itálica, e Deneauve (1969) para o Norte de África, forneceram-nos algumas coordenadas fundamentais, embora seja de lamentar o desconhecimento que normalmente denotam no que respeita às realidades peninsulares. Refira-se, porém, que às próprias carências da arqueologia hispânica se deve assacar boa parte destas responsabilidades.

Nos últimos anos a investigação em Espanha tem progredido significativamente neste domínio, modificando o panorama anteriormente traçado por Pavolini (1981). Assim, pode dizer-se actualmente que as produções tardo-republicanas conheceram ampla difusão na Península Ibérica, acompanhando naturalmente o avanço do processo de romani- 
zação e, por outro lado, o acervo de materiais recentemente publicados inviabiliza qualquer veleidade de cartografia sistemática dos mesmos, que, aliás, não estava de modo algum nos nossos propósitos. No âmbito destes novos estudos, particular interesse nos despertou a publicação dos materiais do acampamento militar romano de Cáceres el Viejo (BeLtran, 1976 e Ulbert, 1984), por se tratar de um estabelecimento de características análogas ás da Lomba do Canho e, naturalmente, o conjunto de Ampúrias, por constituir o mais sistemático e extensamente publicado (ARXÉ I GÁLVEZ, 1982). Este, porém, tem o inconveniente de somente considerar os exemplares de "tipo romano", deixando de fora o conjunto de produções de "tipos helenísticos" de fabrico/importação certamente coevos.

Um conjunto relativamente numeroso e homogéneo como este que apresentamos, constituido por oito exemplares de classificação incontroversa e mais cinco fragmentos, apresenta-se à partida como um contributo importante para o conhecimento do processo de romanização destas regiões, sobretudo porque introduz modificações significativas no panorama actualmente conhecido dos materiais análogos (v. infra e Fig. 6).

Esta situação, contudo, exige uma certa cautela, de modo a evitar que deste panorama se retirem conclusões precipitadas. O peso excessivo que os achados da Lomba do Canho têm resulta de circunstancias particularmente que se prendem tanto com as condições específicas deste sítio arqueológico, como com a situação que a investigação no ámbito da arqueologia clássica conhece entre nós.

O acampamento militar de Arganil apresenta condições particulares, urna vez que, após uma utilização relativamente breve, não voltou a conhecer nenhuma ocupação continuada, ao contrário do que aconteceu a outros lugares habitados na mesma época, normalmente sítios de características urbanas com uma longa diacronia de ocupação, que acaba por produzir uma fragmentação excessiva destes materiais, frágeis e de reduzidas dimensões, dificultando a sua recolha e correcta caracterização. A esta razão se junta certamente uma outra, mais geral, que decorre do estado em que se encontra a investigação arqueológica dos primórdios da ocupação romana no actual território português. Assim, com a publicação dos exemplares de Arganil, fica concentrada no centro do país, na Lomba do Canho e em Conimbriga, a maioria dos achados de lucernas tardo-republicanas registados no extremo Ocidente peninsu- 
lar, o que não corresponde minimamente ao processo de distribuição que estes materiais terão conhecido na Antiguidade...

Como em outros lugares já escrevemos (v. referências da Introdução), temos suficientes evidências para sustentar a hipótese de ter existido um abandono precipitado do estabelecimento militar de Arganil. Tal facto parece demonstrado não só pela abundância e características de deposição do espólio, como pelas grandes quantidades de armamento abandonadas no local. Esta circunstância permite, no caso das lucernas, estabelecer alguns aspectos da sua utilização no quotidiano da guarnição ali instalada. É nítida a distribuição preferencial destes materiais pelas áreas de evidentes funções residenciais (casernas), designadamente nos Sectores B e C. No Sector B - o único de funções residenciais que foi extensamente escavado - constatou-se a ocorrência de uma lucerna por compartimento e, nos casos em que garantidamente se encontraram in situ, aparecem associadas a uma lareira, cumprindo, juntamente e em alternância com esta, uma importante função na vida do destacamento.

De um modo geral, o espólio cerâmico recolhido na Lomba do Canho apresenta-se bastante deteriorado devido à acidez do terreno. No caso concreto das cerâmicas finas (campaniense, paredes finas e lucernas) a situação é ainda mais grave, embora tal deterioração não tenha afectado do mesmo modo a totalidade dos exemplos. Assim, e no que concerne específicamente às lucernas, os $n .^{\text {os }} 1,2,7$ e 8 apresentam-se relativamente bem conservados, mantendo inclusivamente os seus revestimentos externos, nos casos em que existam. Quanto aos restantes, o estado de conservação é bastante mau, carecendo mesmo de impregnação para que se possa assegurar a sua conservação. Naturalmente, nestes casos, os antigos revestimentos desapareceram quase por completo, não resultando fácil determinar, em algumas delas, se efectivamente teriam existido.

\subsection{Catálogo}

n. ${ }^{\circ} 1$ - Lucerna reconstituída enquadrável no tipo $\mathrm{H}$ de Ricci. Foi recolhida na decapagem do Sector $\mathrm{C}$, durante a campanha de escavações de 1982 (v. Fig. 1 e 3).

Dimensões: comprimento máximo $(\mathrm{C}): 8.1 \mathrm{~cm}$; largura máxima $(\mathrm{L})$ : $4.9 \mathrm{~cm}$; altura máxima $(\mathrm{A}): 3.3 \mathrm{~cm}$.

Por se encontrar excepcionalmente bem conservada e, actualmente, restaurada, não resulta fácil a observação da argila que se apresenta 
bastante compacta com uma coloração castanha avermelhada (Mun. 10 YR 5/6) *, com vestígios de um engobe exterior castanho (Mun. 7.5 YR 4/4). Toda a superfície externa se apresenta muito manchada de negro por evidente contacto com o fogo.

Bico alongado, alargando-se na extremidade em tomo do orifício, e fragmentado de um lado. Na zona de ligação entre o bico e o disco ostenta uma marca impressa de feição ovalada com cerca de $0.9 \times 0.7 \mathrm{~cm}$ de difícil leitura (v. Comentário). Disco rebaixado e levemente côncavo. Depósito alto e cilíndrico. Fundo plano, de $4.2 \mathrm{~cm}$ de diâmetro, ligeiramente rebaixado.

n. ${ }^{\circ} 2$ - Metade superior de uma lucerna enquadrável no tipo $\mathrm{H}$ de Ricci. Foi recolhida no decurso do desmonte de um monturo de pedreira, no interior do grande compartimento do Sector A (v. Fig. 1 e 3), nas primeiras intervenções realizadas na Lomba do Canho ainda em finais da década de 50 .

Dimensões: C: $10.5 \mathrm{~cm}$; L: $6.1 \mathrm{~cm}$.

Pasta compacta, embora com diversos elementos não plásticos (e.n.p.) de dimensões muito reduzidas, designadamente quartzo, calcite, elementos negros e mica dourada, de coloração homogénea vermelha (Mun. 2.5 YR 5/8), sem qualquer vestígio de revestimento exterior, provavelmente por se encontrar bastante desgastada.

Bico alongado e de forma rectilínea, com vestígios de negro de fumo junto ao orifício, particularmente no seu interior. Na zona de ligação entre o bico e o disco ostenta uma decoração fálica em relevo. Disco rebaixado.

n. ${ }^{\circ} 3$ - Lucerna inteira, presumivelmente enquadrável no tipo Dressel/Lamboglia 2. Foi recolhida no piso de habitat [UE 36] do Ambiente I do Sector B, ;mediatamente a norte da lareira [UE 7] na campanha de 1982 (v. Fig. 1, 2 e 3).

Dimensões: C: $6.7 \mathrm{~cm}$; L: $5.2 \mathrm{~cm}$; A: $2.4 \mathrm{~cm}$.

Por se encontrar intacta não resulta fácil uma observação da pasta que, no entanto, parece muito compacta e de coloração cinzenta escura (Mun. 5 Y 4/1), bastante manchada de negro, provavelmente devido ao contacto com o fogo, mas, também, seguramente pela utilização.

Bico alongado com ligeiro alargamento na extremidade. Na zona de ligação entre o bico e o disco apresenta uma decoração em relevo de

* Todas as referências de cor reportam-se à Muriseli Soil Color Charts, Solltest Inc., Evanston, 1975.

Conimbriga, 29 (1990), 69-90 
difícil interpretação, mas que poderá ser tomada como uma estilização de batráquio ou, com menor probabilidade, como uma esquematização de intuito fálico. Esta decoração liga-se, por sua vez, a uma moldura circular em relevo que enquadra o disco propriamente dito. Este é marcadamente côncavo a partir da moldura. Ostenta, ainda, sobre o margo, uma decoração em óvulos, dispostos em quatro fiadas paralelas. Apresenta uma única aleta em forma de barbatana. Pé bem marcado, em anel, delimitando o fundo côncavo de $2.9 \mathrm{~cm}$ de diâmetro, que ostenta uma marca incisa (TV, com as extremidades das hastes rematadas por pequenos círculos.

n. ${ }^{\circ} 4$ - Fragmento de disco e margo de uma lucerna seguramente enquadrável no tipo Dr./Lamb. 2. Foi recolhida já fora de contexto num monturo de pedreira na área da Sondagem 2 (v. Fig. 1 e 4), juntamente com um fragmento de reservatório e fundo pertencente à mesma peça, embora não seja possível a ligação entre ambos.

Dimensões: L: $7.6 \mathrm{~cm}$.

Pasta de textura foliácea, com pequeníssimos e.n.p. constituídos por elementos negros e quartzo bem rolado, de coloração homogénea amarela avermelhada (Mun. 7.5 YR 7/6), com o cerne mais escuro, cinzento acastanhado claro (Mun. 2.5 Y 6/2). Superfície exterior muito desgastada, sem qualquer vestígio de revestimento.

Disco acentuadamente côncavo, com o orifício de alimentação bastante largo (1.4 cm de diâmetro). Apesar de se encontrar muito desgastada, são visíveis uma decoração em óvulos sobre o margo, bem como os vestígios do arranque da asa, que seria em fita, e de uma aleta lateral de forma indeterminável. Reservatório arredondado e ostentando igualmente, na metade inferior, vestígios de uma decoração em óvulos. Pé em anel, com $3.8 \mathrm{~cm}$ de diâmetro, pouco destacado, delimitando um fundo côncavo.

n. ${ }^{\circ} 5$ - Fragmento de disco, margo e reservatório de uma lucerna idêntica à anterior. Recolhida durante as primeiras campanhas de escavações, no interior de um dos compartimentos identificados na área da Sondagem 1 (v. Fig. 1 e 4), conservava-se in situ no piso de habitat.

Dimensões: L: $5.8 \mathrm{~cm}$.

Pasta muito compacta, com escassos e.n.p. muito rolados, muito manchados, oscilando entre as tonalidades de castanho escuro (Mun. 7.5 YR 4/4) para o margo e amarelo avermelhado (Mun. 7.5 YR 6/6) para o reservatório. Superfície exterior muito desgatada e sem qualquer vestígio de revestimento. 
Disco côncavo. Margo com vestígios de uma decoração em óvulos. Conserva ainda indícios do arranque da asa, que seria em fita, e de uma única aleta lateral cuja forma é indeterminável. O reservatório, arredondado, possuía também decoração por óvulos.

n. ${ }^{\circ} 6$ - Lucerna muito fragmentada, faltando o bico, parte do reservatório, do fundo e a asa. É, apesar de tudo, seguramente enquadrável no tipo Dr./Lamb. 2, talvez na variante 2A de Ricci. Foi recolhida no decurso da campanha de 1983, no Sector B, no piso de habitat [UE 6] do Ambiente IV (v. Fig. 1, 2 e 4).

Dimensões: L: $6.7 \mathrm{~cm}$; A: $3 \mathrm{~cm}$.

Pasta compacta, com poucos e.n.p. visíveis, de muito pequenas dimensões, designadamente mica e quartzo; coloração homogénea amarela avermelhada (Mun. 7.5 YR 6/6), com vestígios de um "verniz" vermelho na parede externa.

Aparentemente a depressão central do disco estendia-se até ao bico, o que nos faz sugerir a afinidade com a variante $2 \mathrm{~A}$ de Ricci. No entanto, o estado de conservação do exemplar não permite maior precisão na observação. Disco côncavo, margo sem qualquer vestígio de aleta, o que constituiria novidade, embora não seja de excluir a hipótese de ela ter existido de facto, junto da ligação ao bico, numa zona que não se conservou. Pé em anel, saliente, delimitando um fundo plano-convexo.

n. ${ }^{\circ} 7$ - Lucerna restaurada, presumivelmente enquadrável numa variante do tipo Dr./Lamb. 2. Foi recolhida no piso de habitat [UE 23] do Ambiente II do Sector B, junto a um afloramento rochoso a sudoeste da lareira [UE 6], na campanha de 1982 (v. Fig. 1, 2 e 5).

Dimensões: C: $12 \mathrm{~cm}$; L: $6.2 \mathrm{~cm}$; A: $3.1 \mathrm{~cm}$.

Por se encontrar razoavelmente conservada e, actualmente, restaurada não resulta fácil a observação da pasta. Parece bastante compacta com uma coloração dominante amarela avermelhada (Mun. 7.5 YR 6/6), revestida por um espesso "verniz" vermelho (Mun. $10 \mathrm{R}$ 4/6), relativamente bem conservado, que cobria toda a superfície externa.

Bico alongado, com um alargamento na extremidade; não se conservou a zona de ligação ao disco. Este, bastante mal conservado, parece ter sido acentuadamente côncavo. Margo com uma decoração em óvulo de características radiais. Não se conservou qualquer vestígio de aleta, embora possa ter existido uma. A asa é em fita, com três caneluras bem marcadas. $\mathrm{O}$ depósito apresenta também, na metade inferior, uma decoração com óvulos alinhados em fiadas radicais perpendiculares ao plano 
do fundo, de um modo geral mais bem conservada que a do margo. Pé em anel, delimitando um fundo acentuadamente côncavo.

n. ${ }^{\circ} 8$ - Lucerna restaurada, enquadrável no tipo Dr./Lamb. 3. Foi recolhida no piso de habitat do Ambiente III do Sector B, junto à lareira [UE 1], na campanha de 1981 (v. Figs. 1, 2 e 5).

Dimensões: C: $11.2 \mathrm{~cm}$; L: $7.2 \mathrm{~cm}$; A: $2.9 \mathrm{~cm}$.

Pasta bastante compacta, com escassos e.n.p. de difícil observação devido ao restauro, de coloração dominante amarela (Mun. 10 YR 7/6). Conserva um espesso "verniz" que cobre toda a superfície exterior, com tonalidade oscilante entre o negro e o vermelho amarelado (Mun. 5 YR $5 / 6$ e 5/8). Estas variações de cor parecem ter resultado mais de um acidente de cozedura do que das condições de jazida.

Bico alongado com um alargamento na extremidade. A ligação ao disco não se conservou. Este é levemente côncavo com uma moldura que delimita o seu perímetro, dentro do qual se acham outras duas, concêntricas, de menores dimensões. Apresenta duas aletas laterais simétricas, rectangulares, lisas e maciças, de grande simplicidade. Asa em fita com uma única canelura central larga. Pé anular que delimita um fundo plano, de 4,1 cm de diâmetro, com uma marca incisa composta por uma combinação de pequenos círculos, cujo desenho total não é determinável pelo estado de conservação em que foi encontrado.

n. ${ }^{\circ} 9$ - Fragmento de características indetermináveis, visto que tanto pode ser um disco e parede de reservatório de uma lucerna cilíndrica, como um fundo e parede de uma lucerna já de forma tipicamente romana. Foi recolhida entre as pedras do derrube das construções do Ambiente I do Sector B [UE 7], na campanha de 1981 (v. Fig. 1 e 2).

Pasta muito compacta sem e.n.p. visíveis, de cor cinzenta escura (Mun. 5 Y 4/1). Poderia ter um revestimento exterior que, no entanto, não se conservou.

Fundo (ou disco) côncavo com um diâmetro exterior estimado em $5 \mathrm{~cm}$.

n. ${ }^{\circ} 10$ - Asa em fita com duas caneluras centrais, conservando ainda um pequeno fragmento do margo. Foi recolhida nas campanhas dos anos 60, in situ, na área da Sondagem 3, num local onde se recolheram abundantes fragmentos de cerâmica campaniense (v. Fig. 1).

Apresenta o mesmo tipo de pasta e coloração dos exemplares da forma Dr./Lamb. 2 acima referidos e restos de um "verniz" vermelho. 
n. ${ }^{\circ} 11$ - Asa de características idênticas à anterior. Foi recolhida na área da Sondagem 1, num piso de habitat, junto do exemplar n. 5 (v. Fig. 1).

n. ${ }^{\circ} 12$ - Fragmento de bico pertencente a uma lucerna de forma indeterminada. Foi recolhida nos trabalhos de 1977, na área do Sector Q (v. Fig. 1).

Pasta muito friável, sem e.n.p. visíveis, de coloração homogénea castanha muito pálida (Mun. 10 YR 8/3). Conserva vestígios de um "verniz" negro.

n. ${ }^{\circ} 13$ - Fragmento de fundo e depósito de uma lucerna eventualmente enquadrável no tipo Dr./Lamb. 2. Foi recolhida nos trabalhos de 1977, no Sector Q (v. Fig. 1).

Pasta de textura homogénea, sem e.n.p. visíveis, de coloração castanha muito pálida (Mun. 10 YR 7/4). Parece conservar vestígios de um engobe muito escuro.

Pé em anel que delimita um fundo, de $3,2 \mathrm{~cm}$ de diâmetro, inicialmente plano, mas que se toma acentuadamente côncavo na parte central.

\subsection{Comentário}

O conjunto das lucernas da Lomba do Canho documenta de um modo eloquente uma fase de transição no contexto da produção destes utensílios no período tardo-republicano. Assim, ao lado dos últimos representantes de uma longa tradição de raízes helenísticas, ilustrada pelos exemplares do tipo $\mathrm{H}$ de Ricci (n. ${ }^{\text {os }} 1$ e 2), surgem em maior abundância os exemplares do tipo Dr./Lamb. 2, os primeiros de inspiração nitidamente romana. Verifica-se a presença de pelo menos um exemplar do tipo Dr./Lamb. 3, que prefigura as típicas lucernas de volutas do período alto-imperial.

Este carácter de transição fica bem patente na comparação do nosso conjunto com o dos acampamentos do cerco de Numância (Groller, 1927: 254 e Taf. 40; Koenen, 1929: 216, 230 e 301-3, Taf. 53 e 80-82) e de Cáceres el Viejo (Ulbert, 1984: 155-7, 241-2 e Taf. 41-42, 64-65), cronologicamente mais antigos, onde os tipos de feição marcadamente romana estão ausentes. No caso concreto de Cáceres el Viejo, o tipo $\mathrm{H}$ de Ricci é o mais abundantemente representado, com vinte e três exemplares distribuídos por quatro variantes, num total de trinta e seis (ULBERT, 1984: 155). 
Do tipo $\mathrm{H}$ de Ricci registam-se na Lomba do Canho dois exemplares de características nitidamente diferentes. $\mathrm{O} n .^{\circ} 1$ apresenta uma pasta escura e uma marca impressa na ligação entre o disco e o bico de difícil leitura devido ao desgaste que apresenta.

Algumas produções norte-africanas deste tipo apresentam justamente, na ligação entre o bico e o reservatório, marcas impressas com invocações a Tanit em caracteres púnicos (Deneauve, 1969: 16M, n.os 208 a 232). No entanto, outras há, do mesmo tipo, que apresentam em idêntica posição marcas impressas com caracteres latinos (RICCI, 1973: 225 e Fig. 32). Em anteriores trabalhos hesitámos na descodificação da marca do nosso exemplar (GUERRA/FABIÃO, 1988: 315; NUNES/FABIÃO/ GuerRA, 1988: 19 e 1989: 409), todavia, uma limpeza cuidada da sua superfície e uma mais cautelosa observação autorizam-nos a optar pela segunda leitura. Trata-se, de facto, de uma marca que parece apresentar um $\mathrm{S}$ enquadrado por pontos e, talvez, um L. Esta leitura é, aliás confirmada pela rectificação feita por D. Colls (1987: 58) à interpretação de uma marca idêntica recolhida no naufrágio da Colonia de Sant Jordi, Maiorca (CERDA, 1980: 66 e Fig. 94). Este naufrágio, datado do primeiro quartel do séc. I a. C. (COLLS, 1987: 89-90), constitui, por sinal, o mais claro testemunho da exportação de lucernas deste tipo para a Península Ibérica.

$\mathrm{O}$ n. ${ }^{\circ} 1$ da Lomba do Canho apresenta, quer pela pasta, quer pelas dimensões, evidentes afinidades com alguns dos materiais de Cáceres el Viejo (Ulbert, 1984: n.os 485-491) e com um exemplar de Alcácer do Sal (AlmeIDA, 1953: 149 e Est. XXX, 1) - a peça encontra-se em exposição no museu local. Registe-se, porém, que a decoração fálica comum aos materiais de Cáceres e Alcácer sugere um fabrico diferente, provavelmente itálico, eventualmente de um mesmo centro produtor. Refira-se ainda que nenhum exemplar de Cáceres apresenta qualquer marca, apesar de pertencerem ao mesmo âmbito cronológico que o citado exemplar do naufrágio da Colonia de Sant Jordi.

Quanto ao n. ${ }^{\circ} 2$, denota claras diferenças, não só em relação ao $n .^{\circ}$ 1 , como aos paralelos acima referidos. Pela sua pasta avermelhada aproxima-se das produções que Pavolini considera originárias da região do Lácio, eventualmente da própria cidade de Roma (PAVOLINI, 1981: 161). Alguns exemplares procedentes de Cáceres el Viejo, sem qualquer decoração, parecem apresentar pastas semelhantes (n.os 492, 493 e 495). No actual território português, do ponto de vista do fabrico, o paralelo mais próximo que conhecemos para o nosso exemplar foi recolhido no 
Cabeço de Vaiamonte (Monforte) e encontra-se actualmente exposto no MNA (.$^{\circ}$ 46233). Do ponto de vista da forma, porém, enquadra-se na variante $b$ que Ulbert definiu (1984: 156-7). Acrescente-se que não encontramos qualquer paralelo exacto para a decoração fálica que $o$ exemplar da Lomba do Canho exibe. Esta lucerna pode ainda considerar-se invulgar pelo seu comprimento.

As lucernas do tipo $\mathrm{H}$ de Ricci têm sido normalmente descritas como produções montadas a torno, na sequência das tradições helenísticas. Os exemplares da Lomba do Canho, porém, apresentam características de fabrico que parecem claramente sugerir a utilização de moldes. Em primeiro lugar, denotam grande fragilidade na ligação da metade superior e a inferior - no caso do n. ${ }^{\circ} 1$, a peça partiu por essa ligação e do $n .^{\circ} 2$ conserva-se apenas a metade superior; em segundo lugar, o interior desta denota vestígios de impressões de dedos, característica própria das produções em molde; finalmente, a decoração que este mesmo exemplar ostenta apresenta-se de tal modo solidária com a peça que parece excluir qualquer hipótese de aposição.

A cronologia normalmente apontada para este tipo insere-se num espaço de tempo compreendido entre os meados do século II e os meados do século I a. C. (PavolinI, 1981: 152). Ricci refere achados em estratigrafía em Albintimilium, nos estratos VI-A ${ }^{4}$ e VI-A ${ }^{3 c}$, correspondentes à época de Sula, e exemplares de Roma encontrados no Forum cesariano (48-46 a. C.) (Ricci, 1973: 225-6). Os exemplares de Arganil corresponderiam, assim, à última fase de produção, a uma época em que estas lucernas enfrentavam já a concorrência e certamente sofreriam também a influência dos modelos tipicamente romanos. Não é, pois, de estranhar a possibilidade de terem sido já produzidos com molde, à semelhança do que acontecia com aqueles, visto que, inclusivamente, parecem tratar-se de produções itálicas.

O tipo mais ampiamente representado na Lomba do Canho é o chamado Dr./Lamb. 2. Os exemplares atribuíveis a este tipo (n.os 4, 5, 6, 7 e 13) apresentam de uma forma geral uma grande homogeneidade, correspondendo às características desta produção. Distinguem-se pelo fabrico a molde, pela pasta bem depurada e de tonalidades claras e pelo revestimento de "verniz" vermelho. É interessante assinalar que foi precisamente nas lucernas que primeiro se deu a transformação do gosto pelos revestimentos vermelhos, que virá a suscitar mais tarde e de forma independente a emergência da terra sigillata e o concomitante declínio das produções campanienses. As decorações são normalmente constituí- 
das por fiadas de óvulos distribuídas geralmente pelo margo, mas, em alguns casos, estendendo-se à metade inferior do reservatório.

O exemplar n. 3 poderia suscitar algumas dúvidas. De facto, a pasta é, ao que parece, diferente das características destas produções e apresenta a inovação da ausência de asa. No entanto, quer pela típica decoração em óvulos, quer pela marca que ostenta, exclusivamente documentada em produções do tipo Dr./Lamb. 2 (RICCI, 1973: Fig. 34, n.os 23-25 e 27 e ARXÉ I GÁLVEZ, 1982: 73-74 e lam. XXVIII), poderá enquadrar-se neste grupo. Como explicação das diferenças enunciadas, duas hipóteses se afiguram plausíveis para esta situação: ou se trata de um exemplar cuja pasta foi escurecida por um qualquer acidente de cozedura ou utilização, ou corresponde a uma produção diferente, eventualmente uma imitação com origem em algum lugar periférico em relação aos tradicionais centros de produção. Não conhecemos nenhum paralelo exacto para o nosso exemplar - o mais próximo é fornecido por uma das lucernas do naufrágio A de Cap Dramont (Saint-Raphad) em tudo idêntico ao de Arganil, tanto na estilização do batráquio junto ao bico, como na marca incisa no fundo, afastando-se dele, porém, pelas características da pasta, por possuir uma asa em fita e por apresentar decoração em óvulos também na metade inferior do depósito (SANTAMARIA, 1975: 188). A mesma decoração regista-se no exemplar n. ${ }^{\circ} 144$ de Ampúrias (ArXé I GÁlVEZ, 1982: 65-6, Lam. XXIII, 3), bem como outras identificadas em Albintimilium (RICCI, 1973: 190) e Ostia, por sinal do tipo Dr./Lamb. 2. Face ao estado de conservação da parte superior deste exemplar, não será de excluir a hipótese de se tratar, eventualmente, de uma estilização de intuito fálico.

O exemplar $n .^{\circ} 6$, embora se encontre mal conservado, parece corresponder à variante 2-A de Ricci, caracterizada por um rebaixamento na ligação entre o bico e o disco. Não se conhecem os centros de fabrico desta variante, mas quer pelas suas características, quer pela identidade do âmbito cronológico, não é de excluir a possibilidade de se tratar se uma produção do mesmo centro.

O exemplar n. 7 poderá corresponder a uma variante deste tipo, para o qual não encontramos paralelos exactos. Apresenta as mesmas características de pasta e "verniz", no entanto, possui uma decoração peculiar, com óvulos dispostos em cordão, constituindo linhas radiais.

Finalmente deve assinalar-se que, entre os cinco fragmentos de impossibilidade identificação, pelo menos quatro deles poderão enquadrar-se também no tipo Dr./Lamb. 2. 
As lucernas deste tipo foram ampiamente difundidas para Ocidente, como complemento de carga nos navios que transportavam ânforas vinícolas, à semelhança do que aconteceu com a cerâmica campaniense. No entanto, do numeroso conjunto de exemplares deste período recolhidos no decurso das investigações de arqueologia subaquática (RICCI, 1973: 230), apenas nos casos dos naufrágios de La Madrague des Giens (Var) (TCHERNIA/POMEY/HESNARD, 1978: 16) e Dramont A (Saint-Raphael) (SANTAMARIA, 1975: 188) foi possível documentar de forma inequívoca um lote de lucernas destinadas à exportação.

Este tipo de lucernas é normalmente datado do século I a. C. e corresponde, sem dúvida alguma, ao tipo mais difundido neste século. Pavolini (1981: 162) atribui-lhe um âmbito cronológico compreendido entre 70 a. C. e 15 d. C., embora outros autores, designadamente Ricci (1973: 185-7), proponham uma cronologia que se confina ao século I a. C. A estratigrafía da chamada Muralha Robert, de Ampúrias, que poderá ser considerada como um importante indício do fluxo de importações desta cidade, regista uma presença residual de exemplares deste tipo nos estratos II e I, com cronologias compreendidas entre 30-25 a. C. e $37 \mathrm{~d}$. C, enquanto o auge das importações parece localizar-se nos segundo e terceiro quartéis do século I a. C. (ARXÉ I GÁLVEZ, 1982: 72). No actual território português regista-se a presença de materiais deste tipo em Mértola, onde se identificou, sem qualquer referência contextuai, um exemplar intacto com decoração de óvulos no margo e na metade inferior do depósito, ostentando uma marca característica das Dr./Lamb. 2 (ALMEIDA, 1953: 149-50 e Est. XXX, 2) - actualmente integrado no núcleo de exposição permanente do Museu Nacional de Arqueologia (n. ${ }^{\circ}$ 15006); de escavações antigas realizadas no povoado fortificado de Vaiamonte, Monforte, provém um exemplar intacto que, embora mal conservado, apresenta vestígios de decoração com óvulos no margo em exposição no MNA (n. ${ }^{\circ}$ 984.253.1); em Santarém foi recolhido um fragmento que ostenta uma decoração idêntica na metade inferior do depósito, tratando-se, uma vez mais, de uma peça sem contexto (DlOGO, 1984: 116 e Est. I, 5); e em Conimbriga, nas escavações luso-francesas, foram recolhidas seis fragmentos enquadráveis neste tipo, dos quais apenas um apareceu associado a um pavimento de época pré-augústea (Alarcão/ Ponte, 1976: 94 e PI. XXIII).

Seguramente enquadrável no tipo Dr./Lamb. 3, existe apenas um exemplar. Trata-se de uma lucerna com características de fabrico similar às do tipo anteriormente descrito, o que sugere uma produção em ate- 
liers da mesma área. Distingue-se basicamente do tipo anterior pelo quase desaparecimento do margo, passando o disco a preencher a quase totalidade do topo do reservatório. O exemplar da Lomba do Canho (n. ${ }^{\circ}$ ) apresenta as características do tipo 3, simples, de Ricci, isto é, possui duas aletas simétricas lisas, não apresenta qualquer decoração no disco. A marca que ostenta, infelizmente mutilada, apresenta uma combinação de círculos impressos, de que se conhecem diversos paralelos em lucernas dos tipos Dr./Lamb. 2 e, principalmente, Dr./Lamb. 3 (RICCI, 1973: Fig. 34 e ArXÉ I GÁLVEZ, 1982: 73 e Lam. XXVIII).

O âmbito cronológico destas lucernas é genericamente coincidente com o anterior. Pavolini (1981: 162) sugere datas entre 80 e 10 a. C., Ricci (1973: 197) enquadra-as no âmbito do século I a. C. e na estratigrafía da Muralha Robert de Ampúrias aparecem maioritariamente no primeiro quartel do século I a. C., embora subsista residualmente nos estratos II e I, datáveis de entre 30/25 a. C. e 37 d. C. (ARXÉ I GÁLVEZ, 1982: 72). Refira-se ainda que o já citado lote do naufrágio de La Madrague des Giens inclui também exemplares deste tipo (TCHERNIA/ POMEY/HESNARD, 1978: 16).

Como paralelos exactos no actual território português há apenas a referir, entre os materiais publicados, o exemplar $n .^{\circ} 10$ das escavações modernas de Conimbriga, que possui, aliás, uma pasta idêntica à dos exemplares do tipo Dr./Lamb. 2 (ALARCÃO/PONTE, 1976: 95 e PL XXIII) e, presumivelmente, um exemplar intacto encontrado no nivel de fundação do Castelinho dos Mouros, Castro Verde (MaIA/Maia, 1986: 21 e Foto 14).

\section{As lucernas tardo-republicanas no actual território português}

As principais questões que de imediato o conjunto de lucernas da Lomba do Canho suscita são, basicamente, de duas ordens, relacionadas com a cronologia dos materiais e sua localização geográfica. De facto, nas regiões centro e norte do actual território português, excluindo, eventualmente, alguns pontos do litoral, as lucernas constituem um indicador bastante significativo, podendo considerar-se um dos mais seguros indícios de romanização. Por um lado, porque pressupõem o uso de uma técnica de iluminação de características mediterrânicas, cuja utilização nesta área permanece indocumentada para períodos tão antigos, o que sugere, portanto, que era desconhecida; por outro, porque a sua 
presença implica uma estreita ligação com correntes comerciais de longo alcance, uma vez que o fabrico deste tipo de utensílios, pelas características de que se reveste, exige conhecimentos técnicos que, na prática, impediam a sua imitação local.

Os utilizadores de lucernas, nestas regiões e nestes períodos, são certamente pessoas que ou são romanas ou denotam já um elevado grau de assimilação de hábitos culturais mediterrânicos. No caso concreto da Lomba do Canho, por se tratar de um estabelecimento militar romano, a questão da origem ou enquadramento cultural dos utilizadores das lucernas está obviamente esclarecida. Mas, poder-se-á perguntar qual terá sido o papel da expansão militar romana, entenda-se, da presença física dos exércitos romanos, na difusão destas técnicas de iluminação e, consequentemente, dos artefactos que a ela andam ligados, no extremo ocidental da Península.

Infelizmente, os dados de que dispomos são muito escassos e não permitem, de modo algum, fundamentar posições categóricas. No entanto, a escassa informação disponível sugere claramente a existência de uma estreita relação entre a presença militar e a difusão de lucernas nas regiões interiores e centrais do actual território português.

Parece evidente que a origem da difusão da técnica de iluminação a azeite e respectivos utensílios que a serviam está intimamente relacionada, no Mediterrâneo Ocidental, com os horizontes culturais fenício-púnicos, antecedendo, portanto, o processo de romanização. Registe-se, porém, que a sua divulgação entre as populações indígenas peninsulares parece ter-se cingido às regiões litorais meridionais, como sugere um inventário recentemente publicado (BUSSIERE, 1989: fig. 24). No actual território português só temos notícia de lucernas deste tipo no Monte Molião, Lagos (Viana/Formosinho/Ferreira, 1953: 127 e fig. 56) e na necrópole do Olival do Senhor dos Mártires, em Alcácer do Sal (CORREIA (1925) 1972: 166; (1928) 1972: 175-6 e ARThUR, 1952: 377 e fig. 6) - estas últimas integram as exposições permanentes do Museu de Alcácer do Sal e do MNA (n. ${ }^{\circ}$ 982.58.13). Naturalmente, é previsível que futuras investigações venham enriquecer substancialmente este panorama. Todavia, não se afigura provável, no estado actual dos nossos conhecimentos, que as áreas de distribuição dos mesmos se modifiquem de modo significativo.

É claro que não causa qualquer estranheza o achado de lucernas de tipo helenístico em Alcácer do Sal (Arthur, 1952: Fig. 6 e Almeida, 1953: 149 e Est. XXX, 1) - a última das quais integra a exposição per- 
manente do museu local - e, de facto, so é de admirar que não tenham sido até à data identificados outros materiais análogos nos sítios arqueológicos das regiões meridionais do actual território português. Mais interessante se afigura, porém, o conjunto de achados do povoado de Cabeço de Vaiamonte, Monforte, tanto pelas suas características, como pelo âmbito cronológico em que se integra.

Este sítio arqueológico foi estudado sem que se tivessem publicado os respectivos relatórios de escavação, pelo que a totalidade dos seus materiais constitui, infelizmente, um numeroso acervo de artefactos desprovidos dos respectivos contextos. Recolheu-se, ali, um conjunto muito diversificado de lucernas, num total de seis exemplares, dos tipos E, F, G, H de Ricci e uma lucerna aberta, para além do já citado exemplar do tipo Dr./Lamb. 2- materiais expostos no MNA, com os n.os CV 984.418, 46232, 984.253.1, 46231, 46233. Embora se desconheça se todas as peças foram recolhidas num mesmo horizonte cronológico, não deixa de ser notável a semelhança do conjunto, no seu todo, excepção feita ao exemplar do tipo Dr./Lamb. 2, presumivelmente de difusão mais recente no Ocidente peninsular, com o encontrado no acampamento romano de Cáceres el Viejo. Aliás, já noutro lugar tivemos a oportunidade de chamar a atenção para as características, igualmente notáveis, do conjunto de cerâmicas campanienses do povoado da região de Monforte, que então relacionámos com a penetração dos exércitos romanos no rebordo ocidental da Meseta (FABIÃo/ GUERRA, 1985-6).

Com as devidas reservas, decorrentes da natureza da informação disponível, parece-nos natural relacionar estes dois conjuntos e, por isso mesmo, atribuir à presença romana a difusão das lucernas e, consequentemente, da iluminação a azeite entre as comunidades indígenas das regiões mais afastadas do litoral. É importante sublinhar que algumas das lucernas do acampamento de Cáceres, enquadráveis no tipo $\mathrm{H}$ de Ricci, foram encontradas em depósito e sem vestígios de utilização, no interior de uma construção que Schulten interpretou como uma das tabernae da área comercial do estabelecimento militar instalado junto ao forum (Schulten, 1928: 7 e Ulbert, 1984: 152). Assim, se os dados do naufrágio de Colonia de Sant Jordi, de Maiorca, documentam a importação destes materiais para a Península Ibérica (COLLS, 1987: 58), o contexto de deposição das lucernas do acampamento de Cáceres ilustram uma das formas de difusão das mesmas em solo peninsular.

Por idênticas razões, e atendendo aos dados actualmente disponíveis, é aceitável pensar que as lucernas da Lomba do Canho documen- 
tam a introdução deste tipo de artefactos e, consequentemente, desta técnica de iluminação nas regiões do interior do entre Douro e Tejo do actual território português.

As restantes lucernas tardo-republicanas conhecidas no extremo Ocidente peninsular - o exemplar do tipo Dr./Lamb. 2 de Mértola (AlmeIDA, 1953: 149-150 e Est. XXX, 2); o do tipo Dr./Lamb. 3 do Castelinho dos Mouros, Castro Verde (Maia/MaiA, 1986: 21 e Foto 14); os do tipo 1-A e 1-B recolhidos algures na Serra de Sintra (FERREIRA/ Tavares, 1954: 24-6, Est. I, n. ${ }^{\circ} 2$ e II, n. ${ }^{\text {os }} 3$ e 4); o do tipo Dr./Lamb. 2 de Santarém (DlOGO, 1984: 116 e Est. I, 5) — foram todas recolhidas em locais já de há muito dominados pelos romanos, pelo que não constituem, de modo algum, novidade ou facto surpreendente. Interrogações particulares suscitam, porém, o conjunto de Conímbriga, principalmente por se circunscrever a exemplares dos tipos Dr./Lamb. 2 e 3, sem vestígios de materiais mais antigos (ALARCÃO/PONTE, 1976); ou a notória ausência de materiais destes tipos nos povoados do Noroeste peninsular. Tratando-se, em ambos os casos, de sítios ampiamente estudados, não deixa de causar alguma perplexidade a ausência de tipos mais antigos no primeiro sítio, e a completa inexistênpia de lucernas tardo-republicanas nos outros.

\section{Cronologia}

As lucernas romanas são normalmente consideradas como bons elementos de aferição de cronologias. Contudo, a ampla diacronia da produção dos diferentes tipos tardo-republicanos aparentemente inibiria uma proposta muito precisa de datação para os contextos em que são encontrados. Tal não é o caso da Lomba do Canho. Aqui, muito mais do que a cronologia dos tipos em si, conta a cronologia atribuível a um conjunto com estas características.

$\mathrm{Na}$ Lomba do Canho o que encontramos é verdadeiramente um momento de transição no contexto das produções de lucernas no mundo romano. Subsistem, lado a lado, os últimos fabricos de clara inspiração helenística, com as primeiras produções característicamente romanas. Nas lucernas, tal como aconteceu com as cerâmicas de verniz negro ou as ânforas, o mundo apropriou-se de uma tradição anterior que assimilou, passando depois a criar os seus próprios modelos que, no decurso do século I a. C., se tomariam esmagadoramente maioritários no Ocidente mediterrânico. 
Deste modo, o conjunto da Lomba do Canho assume uma inusitada relevância cronológica, particularmente quando comparado com outros conjuntos da Península Ibérica. Merecem-nos especial atenção os de Cáceres el Viejo e Ampúrias. O primeiro por se tratar de um estabelecimento funcionalmente similar ao de Arganil, o segundo por ter constituído, desde a primeira hora, o principal foco de difusão dos factores e elementos de romanização.

Tal como foi demonstrado pelo estudo comparativo dos materiais dos acampamentos do cerco de Numância e o do de Cáceres el Viejo, é possível discernir variações significativas de relevância cronológica quando se analisa a composição de um conjunto de lucernas (ULBERT, 1984: 159-160). Assim, verificamos que em Cáceres, um acampamento militar datável do primeiro terço do século I a. C. (idem: 203), predominam as lucernas de tradição helenística, estando praticamente ausentes as produções consideradas tipicamente romanas. Quanto a Ampúrias, verifica-se que estão representados os principais tipos de lucernas de modelos romanos que a cidade teria importado, sendo até aos meados do século I a. C. predominantes os exemplares do tipo Dr./Lamb. 2, passando depois a assumir maior relevância o tipo Dr./Lamb. 4 (ARXÉ I GÂLVEZ, 1982: 72), totalmente ausente na Lomba do Canho.

Deve sublinhar-se que os restantes materiais de cronologia segura - moedas, campanienses, ânforas, fíbulas e paredes finas - confirmam plenamente este âmbito cronológico circunscrito ao segundo e terceiro quartéis do século I a. C

No entanto, há um aspecto importante a ter em consideração. Como atrás se viu, o grosso das lucernas apresentadas foi recolhido nas áreas residenciais do estabelecimento militar, ainda insuficientemente investigadas. Deste modo, os resultados agora apresentados, embora coerentes, carecem de uma mais ampla confirmação, razão pela qual se vem tornando cada vez mais urgente o retomar dos trabalhos neste importante sítio arqueológico. 


\section{BIBLIOGRAFIA}

Alarcão, A. M. e PONTE, M. S. 1976: Les lampes, in: Fouilles de Conimbriga. VI. Céramiques diverses et verres, Paris, Diffusion de Boccard, pp. 93-114.

ALMEIDA, J. A. F. 1953: Introdução ao estudo das lucernas romanas em Portugal, in: "O Arqueólogo Português", n. s., 2, pp. 5-208.

ARTHUR, M. L. C. 1952: Necrópolis de Alcácer do Sal, in: II Congreso Nacional de Arqueologia (Madrid, 1951), Zaragoza, pp. 369-380.

ARXÉ I GÁLVEZ, J. 1982: Les IVanties tardo-republicanes d'Empúries, "Monografies Emporitanes", 5, Barcelona.

Beltran Lloris, M. 1976: La ceramica del campamento de Caceres el Viejo (Caceres), in: V Congresso de Estudios Estremeños (Ponencias VII e VIII), Badajoz, pp. 3-22.

BUSSIERE, J. 1989: Les lampes phénicopuniques dAlgérie, in: “Antiquités Africaines”, 25, pp. 41-68.

Cerdá JuAn, D. 1980: La nave romana-republicana de la Colonia de Sant-Jordi. Ses Salines - Mallorca, Palma de Maiorca.

COLLS, D. 1987: LÉpave de la Colonia de Sant Jordi 1, Paris, Diffusion de Boccard.

CORREIA, V. (1925) 1972: Uma conferência sobre a necrópole de Alcácer do Sal, in: Obras IV. Estudos Arqueológicos, Coimbra, pp. 151-167 (primeiramente publicado in: "Biblos", 1 (7), pp. 347-363); (1928) 1972: Escavações realizadas na necrópole pré-romana de Alcácer do Sal em 1926 e 1927, in: Idem, pp. 169-179 (primeiramente publicado in: "O Instituto", 75, pp. 190-201).

DENE AU VE, J. 1969: Lampes de Carthage, Paris, CNRS.

DloGO, A. M. D. 1984: O material romano da primeira campanha de escavações na Alcáçova de Santarém (1979), in: "Conimbriga", 23, pp. 111-142.

FABĨ̃O, C. 1989: Sobre as anforas do acampamento romano da Lomba do Canho (Arganil), "Cadernos da UNIARQ", 1, Lisboa, UNIARQ-INIC.

FABIÃO, C. e GUERRA, A. 1985-86: A cerâmica campaniense do acampamento da Lomba do Canho, Arganil, in: "Clio/Arqueologia", 2 (no prelo); 1987: Considerações preliminares sobre a cerâmica comum do acampamento militar romano da Lomba do Canho, Arganil, in: Da Pré-História à História — Estudos em Homenagem a O. Veiga Ferreira, Lisboa, Delta, pp. 287-308.

FARIA, A. M. 1982: Espólio monetário do acampamento romano de Arganil, "Trabalhos do Museu Regional de Arqueologia", 2, Arganil; 1984-5: As moedas do acampamento romano da Lomba do Canho (Arganil), in: "Nvmmvs", 2. a série, 7-8, pp. $37^{\wedge} 2$.

FERREIRA, O. V. 1961: Cerâmica negra de tipo grego encontrada em Portugal, in: "Arqueologia e História", 9.a série, 3, pp. 313-332.

FERREIRA, O. V. e TAVARES, J. C. 1954: Objectos luso-romanos da Serra de Sintra, in: "Revista de Guimarães", 64, pp. 23-30.

Groller, M. V. 1927: Die Fundstücke, in: SCHULten, A. 1927: pp. 245-268, particularmente p. 254 e Taf. 40 (7-11).

GUERRA, A. e FABIÃO, C. 1988: Escavações no acampamento romano da Lomba do Canho (Arganil): Resultados preliminares, in: Actas l. ${ }^{\text {r r }}$ Congreso Peninsular de Historia Antigua, I, Santiago de Compostela, pp. 307-328.

KOENEN, K. 1929: Die Keramik, in: SCHULTEN, A. 1929: pp. 284-305, especialmente pp. 301-303 e Taff. 53 e 80-82.

Conimbriga, 29 (1990), 69-90 
MAIA, M. e MAIA, M. 1986: Arqueologia da área mineira de Neves Corvo. Trabalhos realizados no triénio de 1982-4, s/1, Somincor.

NUNES, J. C. 1958a; Broches-fibulas em castros portugueses, in: "Zephyrus", 9, pp. 231-233. 1958b: Novos elementos para o estudo da arte castreja em Portugal, in: "Revista de Guimarães", 68, pp. 5-17; 1959: Fíbulas de tipo Nauheim no castro da Lomba do Canho, em Arganti, in: "Revista de Guimarães", 69, pp. 5-23; 1985: Acampamento romano da Lomba do Canho, 1982-83, in: "Informação Arqueológica", 5, p. 71; 1986: Sob o signo do "ramo de ouro" virgiliano, in: VV. AA., Virgílio e a Cultura Portuguesa (Actas do Colóquio do bimilenário da morte de Virgílio, Lisboa, 1981).

Nunes, J. C; FABIÃO, C.; GUERRA, A. 1988: O acampamento militar romano da Lomba do Canho (Arganil), Arganil, Museu Regional de Arqueologia; 1989: Acampamento militar romano da Lomba do Canho, Arganil: O ponto da situação, in: Actas do I Coloquio Regional de Arqueologia de Viseu (Viseu, 1988), Viseu, pp. 403-424.

PAVolin, C. 1981: Le lucerne nell'Italia romana, in: GlARDINA, A. e SCHIAVONE, A. (dir.) Società romana e produzione schiavistica. II. Merci, mercati e scambi nel Mediterraneo, Bari, Laterza, pp. 139-184 e 278-288.

RICCI, M. 1973: Per una cronologia delle lucerne tardo-republicane, in: "Rivista di Studi Liguri”, 39, pp. 168-234.

SANTAMARIA, C. 1975: L'Épave A du Cap Dramont (Saint-Raphael): Fouilles de 1971-74, in: "Révue Archéologique de Narbonnaise", 8, pp. 185-189.

Schulten, A 1927: Numantia III. Die Lager des Scipio, München, Verlag von F. Bruckmann. 1928: Castra Caecilia. Erster Bericht, in: "Archaeologischer Anzeiger", 43 (I), 1-14; 1929: Numantia IV. Die Lager bei Renieblas, München, Verlag von F. Bruckman.

TChernia, A.; Pomey, P.; Hesnard, A. 1978: Lépave romaine de la Madrague des Giens (Var), "34. " Suppl, de Gallia", Paris, CNRS.

ULBERT, G. 1984: Caceres el Viejo. Ein spätrepublikanisches Legionslager in Spanisch- Estremadura, "Madrider Beitrage", 11, Mainz-am-Rhein.

VIANA, A.; FORMOSINHO, J.; FERREIRA, O. V. 1953: De lo prerromano a lo arabe en el Museo Regional de Lagos, in: "Archivo Español de Arqueologia", 26 (87), pp. 113-138. 


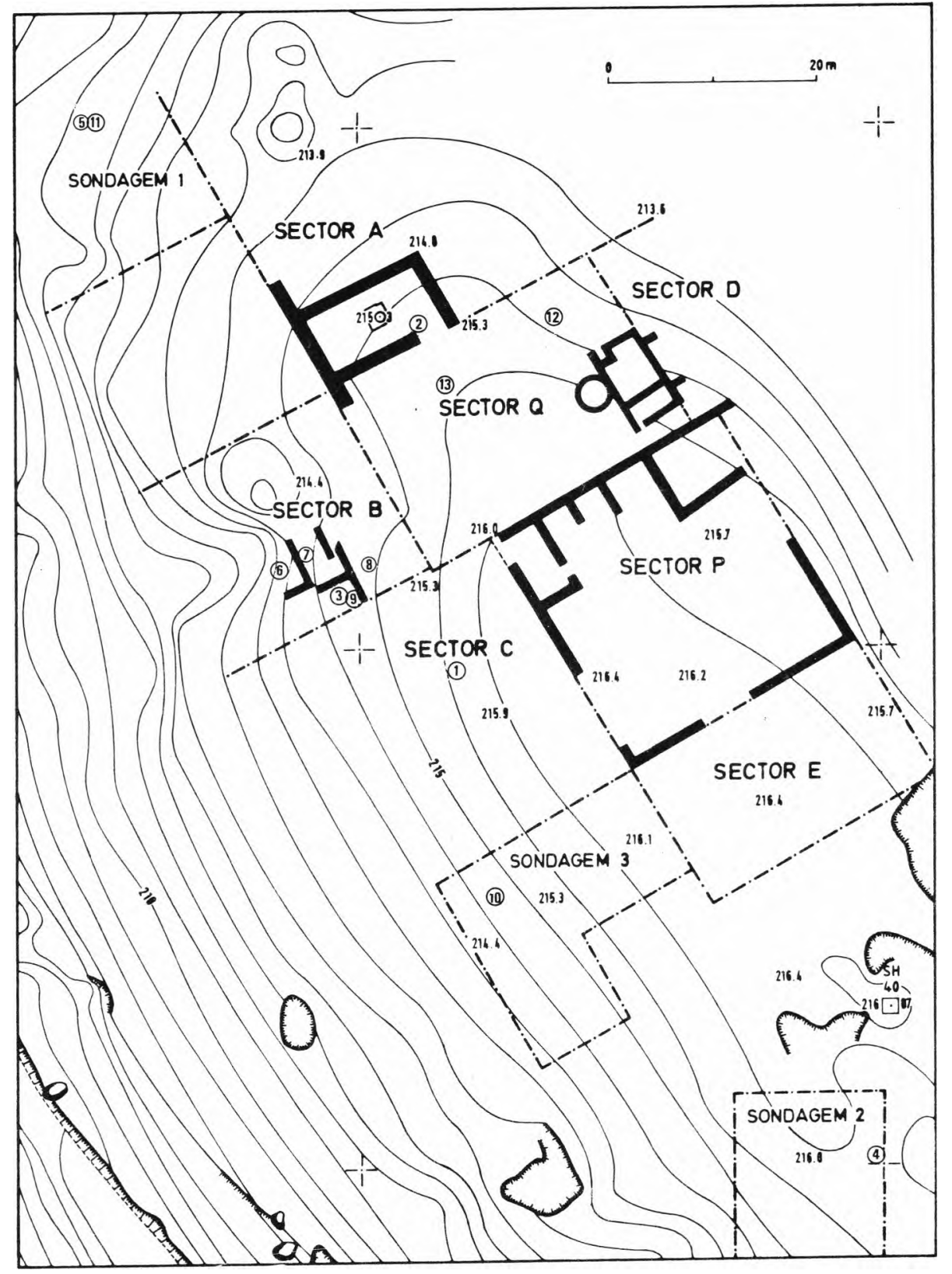

FIG. 1 


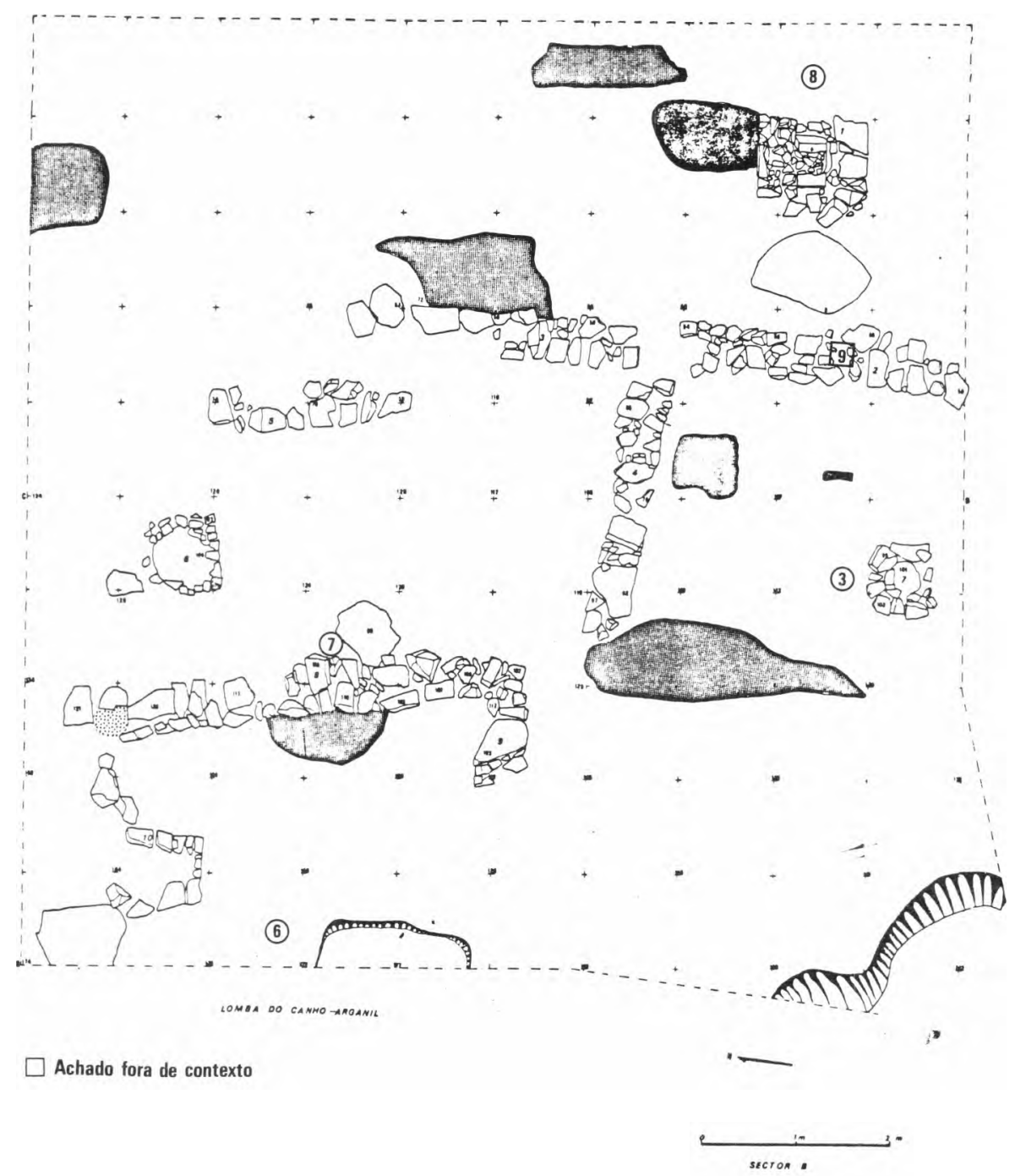

FIG. 2 


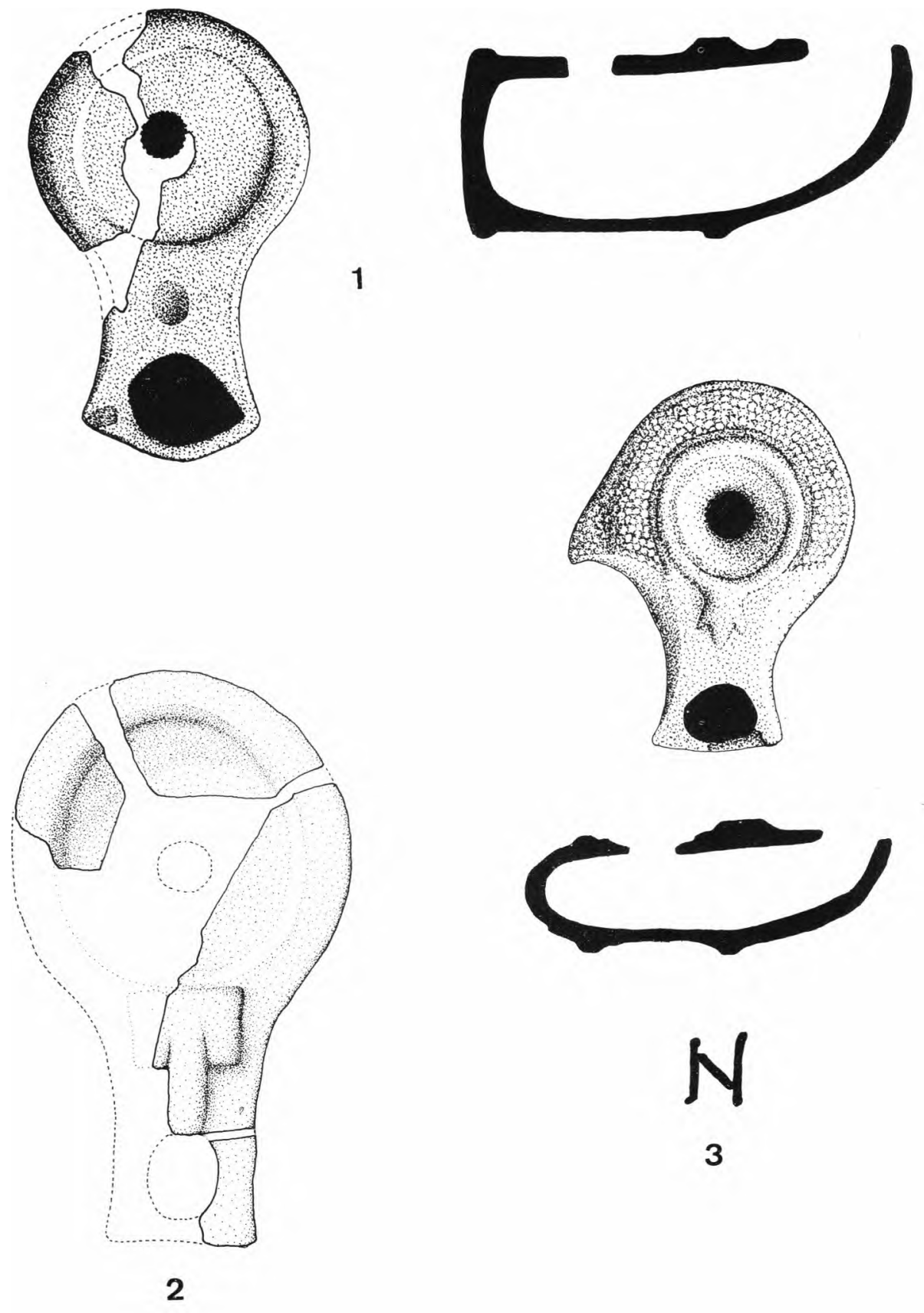

FIG. 3 

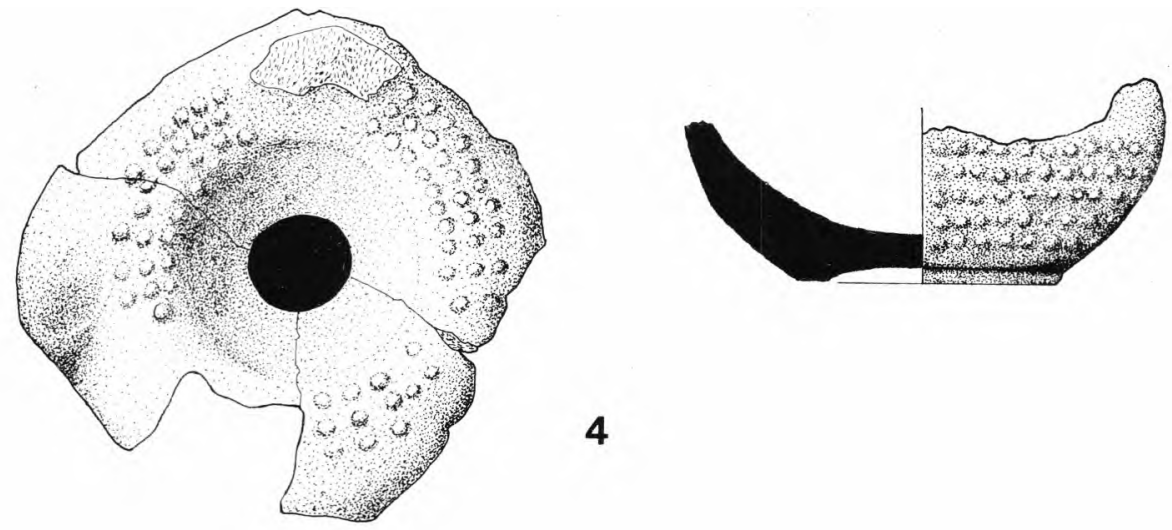

4
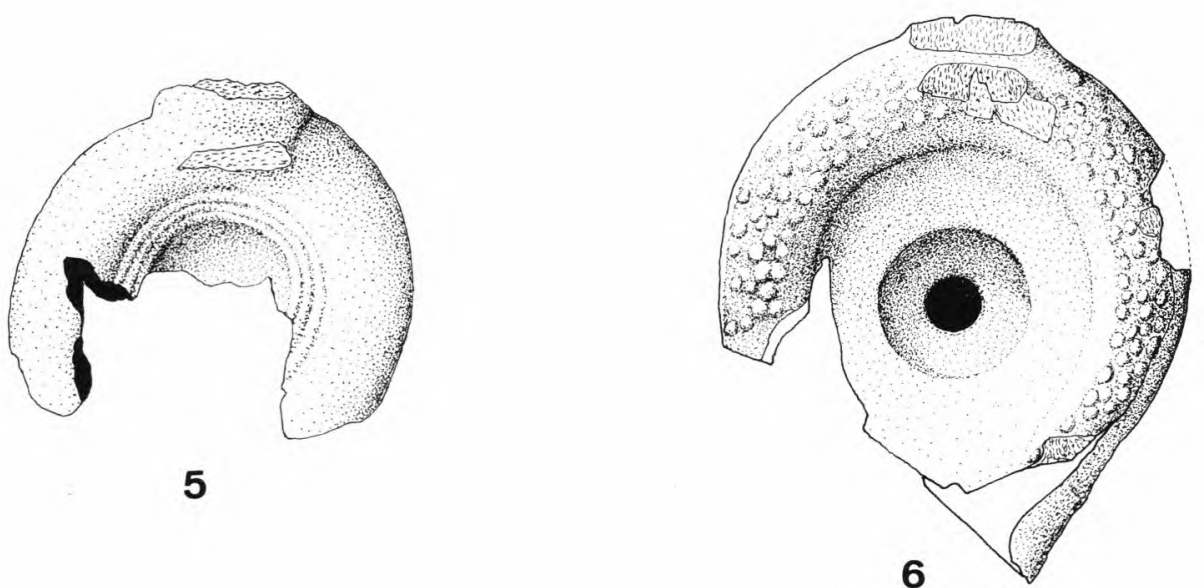

FIG. 4 

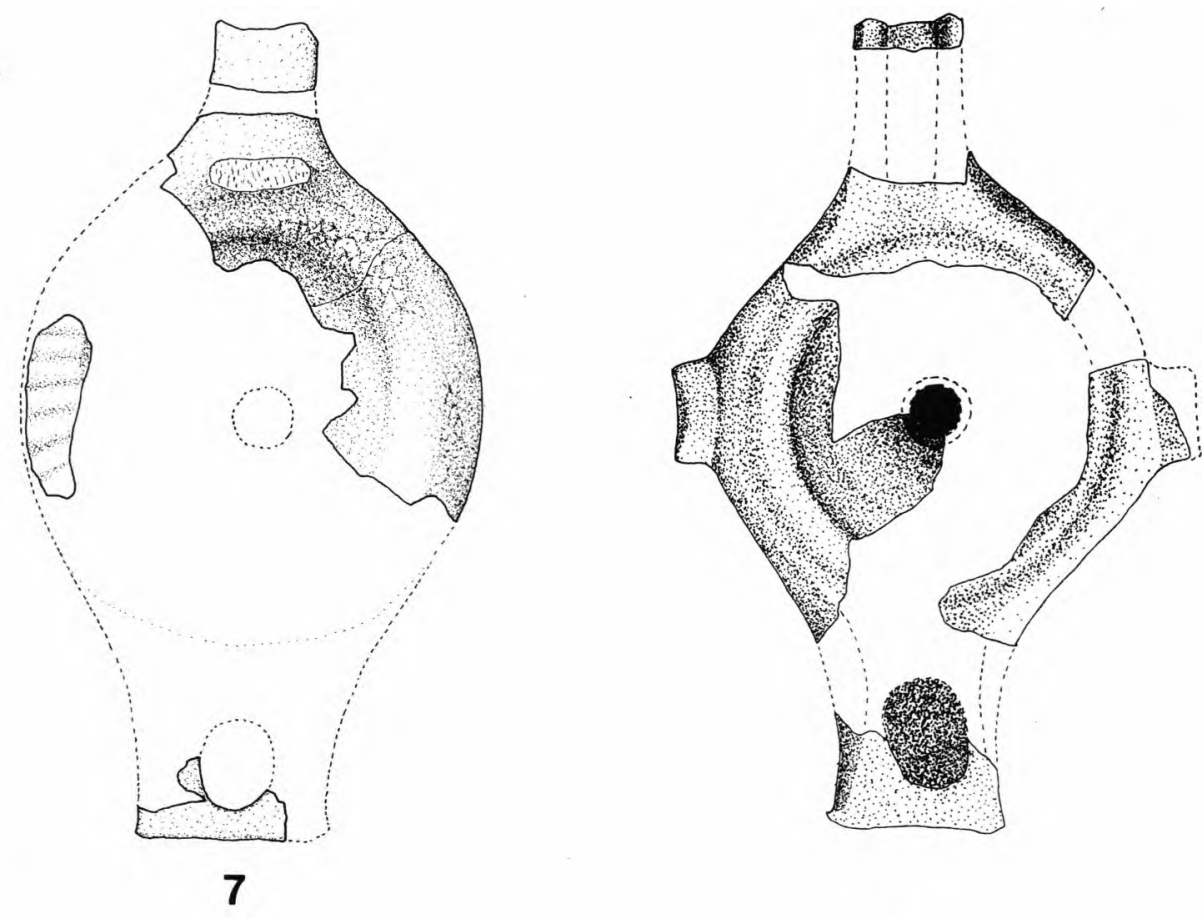

8

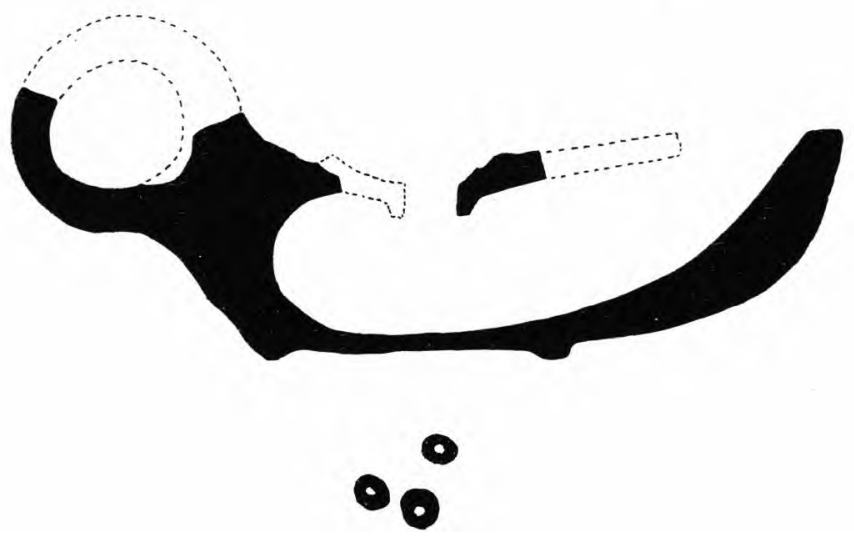

FIG. 5 


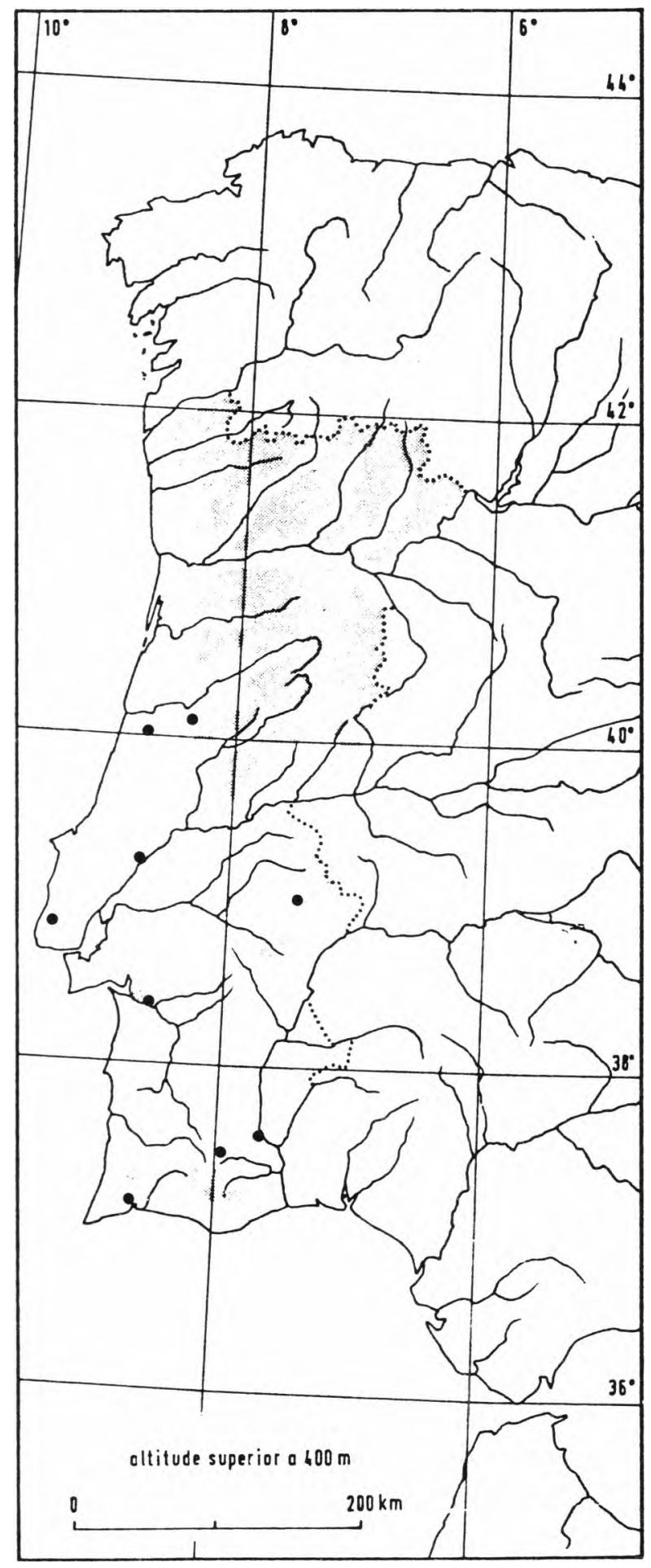

FIG. 6 